\title{
Endogenous circadian rhythm in the river puffer fish Takifugu obscurus
}

\author{
W. S. Kim* , J. M. Kim, S. K. Yi, H. T. Huh \\ Marine Biotechnology Lab., Korea Ocean Research \& Development Institute, Ansan, PO Box 29, Seoul 425-600, Korea
}

\begin{abstract}
Oxygen consumption rate of 8 to 12 mo old river puffer fish Takifugu obscurus was determined using an automatic intermittent-flow-respirometer (AIFR). During the experiments, the fish were not fed and were kept in constant darkness and at constant temperature to avoid any extrinsic disturbances. It was clearly demonstrated that this species has a strong endogenous circadian rhythm in its instantaneous rates of oxygen consumption, although there were weak minor peaks of 11.4 to $11.7 \mathrm{~h}$ intervals. This endogenous rhythm appeared to be independent of the number of fish in the experimental chamber. The endogenous rhythm in the oxygen consumption rate observed in the present study may have profound implications for the physiological processes and biological rhythms of this species, and could also be a good reference in determining the oxygen consumption rates of other aquatic organisms.
\end{abstract}

KEY WORDS: Endogenous circadian rhythm - Oxygen consumption - River puffer fish - Takifugu obscurus

\section{INTRODUCTION}

Ever since a tidal rhythm in behaviour was first discovered in the green turbellarian Convoluta roscoffensis in 1903 (Bohn 1903, Gamble \& Keeble 1903), many researchers have observed the circadian and circatidal rhythms in many species of marine animals (Reid \& Naylor 1989, Northcott et al, 1991, Palmer \& Williams 1993, Tankersly \& Forward 1994, Akiyama 1995, Zeng \& Naylor 1996).

Previous studies of circadian or circatidal rhythms of marine organisms have focused on coincidence of the free-running and locomotor activity rhythm of freshly collected specimens with the environmental pattern at the collection site. Persistent activity rhythm of a single individual was observed in the fiddler crabs Uca minax and U. pugnax (Palmer 1988, 1989), and in the mussel Mytilus edulis (Ameyaw-Akumfi \& Naylor 1987), but the individual rhythms in oxygen consumption were not tracked in those studies. Some investigations on the rhythms in oxygen consumption in

•E-mail: waskim@sari.kordi.re.kr marine animals have been carried out (Aldrich \& McMullan 1979, Marsh \& Branch 1979, Hastings 1981, Fanta et al. 1990, Aagaard et al. 1991, Mehner \& Wieser 1994). However, the observation of an endogenous rhythm associated with oxygen consumption rate in aquatic animals was hindered by lack of proper methodology for determining oxygen consumption, and by technical difficulties in avoiding extrinsic disturbances which affect the biorhythm of the test organism, in previous studies.

Most respirometers (closed and flow-through) are incapable of correlating oxygen uptake with defined activity patterns, which limits their usefulness in bioenergetics studies (Wrona \& Davies 1984). The advantages and disadvantages of certain respirometers have also been intensively reviewed by a number of researchers (Lampert 1984. Wrona \& Davies 1984 , Steffensen 1989, Davies et al. 1991). Recently, the limitations imposed by earlier procedures were alleviated by new techniques which allow non-invasive monitoring of certain rate processes in selected animals using computer-aided data acquisition and storage systems (Aagaard et al. 1991, Davies et al. 1991, Dorrien 1993) 
An automatic intermittent-flow-respirometer (AIFR) employs such techniques and was used to eliminate some of the problems associated with traditional respirometers (Kim et al. 1996a). The AIFR was specially designed by modifying Dorrien's (1993) respirometer with much improved software. It was hoped that use of this sensitive respirometer would yield results in the long-term oxygen consumption rate of fish with greater reliability than the short-term measurements of respiration using conventional methods

The present study was carried out to determine the possible occurrence of an endogenous circadian rhythm in oxygen consumption of the river puffer fish Takifugu obscurus, which is endemic to Korean and Chinese waters (Chyung 1977).

\section{MATERIALS AND METHODS}

Experimental organisms. The river puffer fish Takifugu obscurus used in the experiment were spawned as a result of artificial insemination and reared in a culturc tank (100 1) for 8 to 12 mo at the Korea Occan Research and Development Institute (KORDI). Test subjects $[6.5 \pm 0.1 \mathrm{~cm}$ total length, $1.10 \pm 0.03 \mathrm{~g}$ dry wt $(\bar{X} \pm \mathrm{SE})]$ were acclimated to the experimental temperature of $15^{\circ} \mathrm{C}$ for $4 \mathrm{wk}$. In 11 experiments, 41 fish were monitored, with 1,4, or 6 fish being put in one chamber at a time (Table 1). Feeding of fish was stopped $48 \mathrm{~h}$ before their introduction into the test chamber, and fish were not fed during the experiments.

Experimental design. The oxygen consumption rate was measured by the AIFR ( 1 system with 2 chambers) The AIFR has a greater flexibility in determining the oxygen consumption at various interval levels (seconds) and oxygen tensions than other types of respirometer. Seawater $(30.1$ to $30.5 \%$ o) was filtered free of bacteria through sterile membrane filters (with 2 Sartorius Capsule Filters, input $0.2 \mu \mathrm{m}$ and output $0.07 \mu \mathrm{m})$. Oxygen levels in the experimental 0.3 (1 fish) and 1.41 chambers ( 4 and 6 fish) were maintained between 95 (highest) and $86 \%$ (lowest) of saturation. The measuring system was installed in a constantly darkened incubator (MLR-350, REVCO, USA) with a constant temperature of $15^{\circ} \mathrm{C}$. The magnetic drive gear pump (MS-Z, Ismatec Sa, Switzerland) installed produced a horizontal water flow at rates of 345 and $690 \mathrm{ml} \mathrm{min}{ }^{-1}$ During the experiments, water temperature and air pressure were continuously moni- tored using a thermometry sensor (Pt-100, Farnell, Germany) and a barometric pressure sensor (Sensym Hs 20, Farnell), respectively. Salinity (\%) was measured with a salinometer (LF 320, WTW, Germany). The oxygen consumption rate was calculated using the formulae of Dorrien (1993) and Weiss (1970). When the oxygen level dropped below the predetermined limit, the magnetic drive gear pump and 3-way magnetic valve (332F, Nortec, Germany) supplied the system with saturated seawater until the selected oxygen level was reached. After each experiment, the chamber was rinsed with oxygen-saturated water and the probe voltage was examined to ascertain whether it had deviated from the gauge voltage at the beginning of the experiment. After calibration of the oxygen probe (15 $\mu \mathrm{PO}_{2}$, Eschweiler, Germany), the measuring system was started and the experiment was controlled automatically by a computer program. At every second the actual oxygen leveis were recorded by the digital controlling unit through a picoammeter. Oxygen consumption values for the test organisms were calculated every $90 \mathrm{~s}$ by the computer and the calculated mean oxygon consumption was displayed graphically every $90 \mathrm{~s}$. The time series of oxygen consumption were continuously recorded. No measurements were made while flushing the chamber with oxygen saturated seawater from a storage tank (10 l) to restore the upper oxygen level to $95 \%$ of saturation. Data readings, including local and experimental time (seconds), temperature $\left({ }^{\circ} \mathrm{C}\right)$, air pressure ( $\left.\mathrm{hPa}\right)$, oxygen consumption $\left(\mathrm{ml} \mathrm{O} \mathrm{O}_{2} \mathrm{~h}^{-1}\right)$ and oxygen levels $(\%)$, were stored directly in a hard disk drive for future analysis. More detailed descriptions of calculation methods and schematic of the apparatus are given in Kim et al. (1996a).

Table 1. Takifugu obscurus. Experimental parameters and oxygen consumption rates for the 1,4 , and 6 river puffer fish groups. Statistical values were computed for each batch from the 1843 to 3185 data points measured. Values are means ( \pm SE where given)

\begin{tabular}{|c|c|c|c|}
\hline & 1 Fish & 4 Fish & 6 Fish \\
\hline Total length $(\mathrm{cm})$ & 6.4 & 5.9 & 6.0 \\
\hline Wet weight $\left(g\right.$ ind $\left.^{-1}\right)$ & 9.6 & 7.6 & 7.6 \\
\hline Temperature $\left({ }^{\circ} \mathrm{C}\right)$ & $15.1 \pm 0.001$ & $14.6 \pm 0.004$ & $14.5 \pm 0.005$ \\
\hline Salinity $(\%)$ & 30.5 & 30.1 & 30.1 \\
\hline Levels of oxygen saturation ( $\%$ ) & $\begin{array}{c}94.9-91.3 \\
( \pm 0.01)\end{array}$ & $\begin{array}{l}94.9-86.3 \\
( \pm 0.04)\end{array}$ & $\begin{array}{l}94.4-86.8 \\
( \pm 0.05)\end{array}$ \\
\hline Chamber volume (1) & 0.3 & 1.4 & 1.4 \\
\hline Flow volume ( $\mathrm{ml} \mathrm{min}^{-1}$ ) & 345 & 690 & 690 \\
\hline Duration of the experiment (h) & 198.1 & 120.3 & 88.1 \\
\hline Number of points measured & 2765 & 3185 & 1843 \\
\hline Measurement interval (s) & 90 & 90 & 90 \\
\hline $\begin{array}{l}\text { Oxygen consumption rate } \\
{\left[\mathrm{ml} \mathrm{O}_{2}(\mathrm{~g} \text { dry } w)^{-1} \mathrm{~h}^{-1}\right]}\end{array}$ & $0.69 \pm 0.01$ & $0.79 \pm 0.01$ & $0.91 \pm 0.01$ \\
\hline Number of experiments & 3 & 5 & 3 \\
\hline Total number of fish & 3 & 20 & 18 \\
\hline
\end{tabular}


Fig. 1. Time series of oxygen consumption rate $\left(\mathrm{ml} \mathrm{O}_{2} \mathrm{~h}^{-1}\right)$ by (A) 1 river puffer fish Takifugu obscurus $(9.6 \mathrm{~g}$ wet wt) during about $8 \mathrm{~d}$, (B) 4 fish (30.4 $\mathrm{g}$ wet wt) during $5 \mathrm{~d}$, and $(\mathrm{C}) 6$ fish (45.6 g wet wt) during $4 \mathrm{~d}$. (o) Mean oxygen consumption rates over $90 \mathrm{~s}$. Arrows indicate peaks of oxygen consumption at around 08:00 h
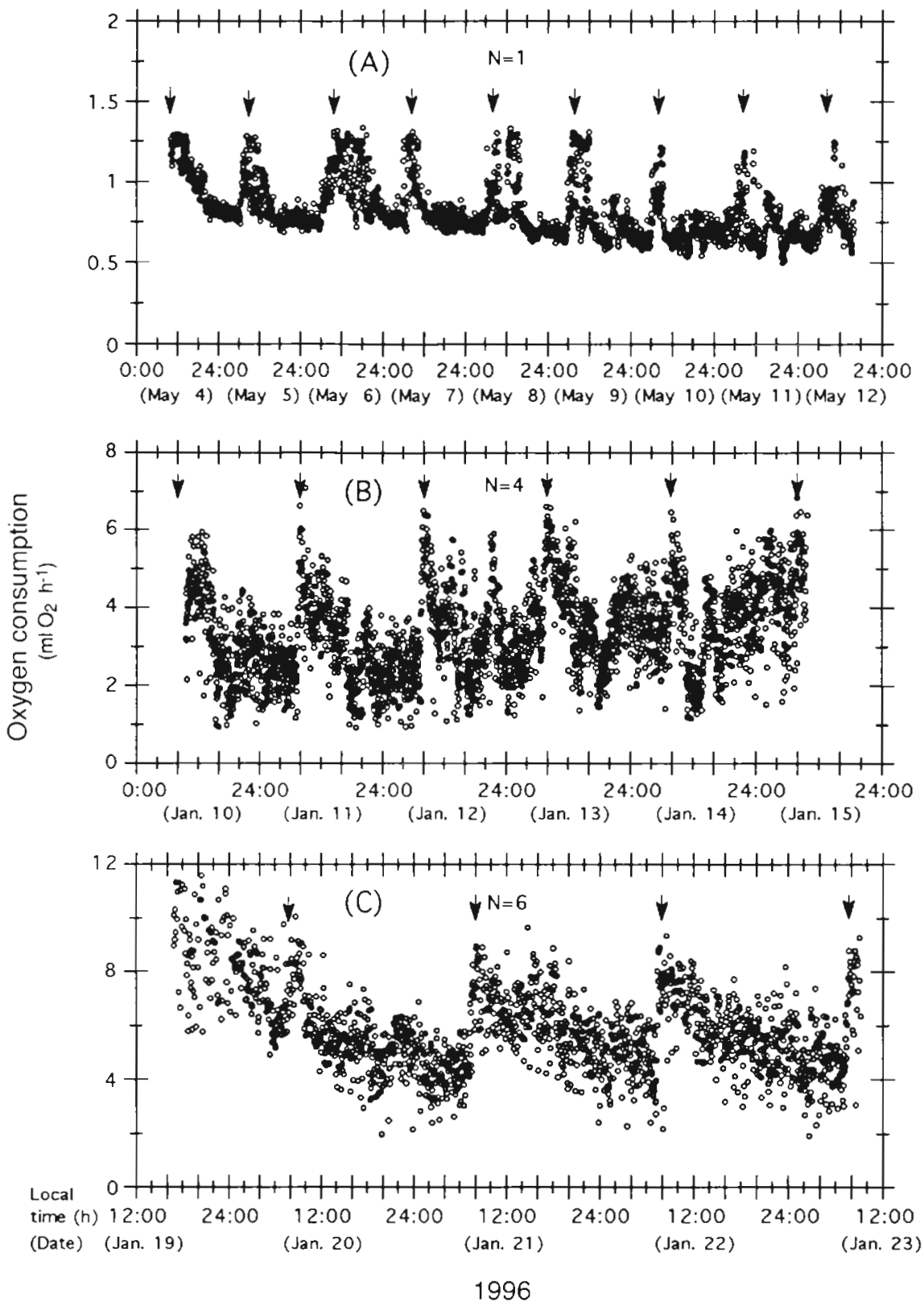

Analysis of oxygen consumption records. Rhythmicity was determined by plotting with a Maximum Entropy Spectral Analysis (MESA) program using raw data transformed into $40 \mathrm{~min}$ lag intervals. Time series were analysed for periodicity using MESA spectra following the procedures and algorithms described by Dowse \& Ringo (1989).

\section{RESULTS}

The oxygen consumption rates of the river puffer fish in 3 sets of experiments (with 1, 4, and 6 fish in a test chamber, respectively) measured during January through May 1996 are shown in Table 1

The instantaneous rates of oxygen consumption exhibited a rhythmicity throughout the experiments in both single and grouped river puffer fish. The frequencies of rhythmicity observed were 8 cycles in the period of $8.3 \mathrm{~d}(198.1 \mathrm{~h})$ for 1 fish and 5 cycles in $5.0 \mathrm{~d}$ $(120.3 \mathrm{~h})$ in the 4 fish group. In the 6 fish group, however, the rhythmicity was not evident during the first $12 \mathrm{~h}$, possibly due to stress; this group, therefore, showed 3 cycles in $3.7 \mathrm{~d}(88.1 \mathrm{~h})$.

The mean oxygen consumption rate in the rhythms of the 1 fish appears to gradually decrease with time 
$(r=0.86, p<0.05 ;$ Fig. 1A), while they gradually increased in the 4 fish group $(\mathrm{r}=0.94$, $p<0.05$; Fig. 1B). The oxygen consumption rate of the 6 fish group was higher during ca the first $13 \mathrm{~h}$ than in the later part of the experiment (Fig. 1C).

The river puffer fish maintained a relatively low uptake of oxygen consumption during the night (which is referred to as the 'basal' rate in this paper), even though they were kept in constant darkness. Thereafter, the rate of oxygen consumption dramatically increased, reaching the peak at early morning, 1 to $2 \mathrm{~h}$ after sunrise (indicated by arrows, Fig. 1), in all experiments. The amplitude of the oxygen consumption rate ranged from 0.5 to $1.3 \mathrm{ml} \mathrm{O}_{2} \mathrm{~h}^{-1}$ for the 1 fish, from 0.9 to $7.3 \mathrm{ml} \mathrm{O}_{2} \mathrm{~h}^{-1}$ in the 4 fish group, and from 1.9 to $11.7 \mathrm{ml} \mathrm{O}_{2} \mathrm{~h}^{-1}$ in the 6 fish group, respectively, showing a large variation between the 'basal' rate and high uptake of oxygen.

Fig. 2 shows the MESA spectra of each of the data sets presented in Fig. 1. The peaks in oxygen consumption mainly occurred at 24.6 and $24.8 \mathrm{~h}$ intervals, which corresponds with a circadian rhythm, as shown by MESA spectral density (Fig. 2A, B). However, the peak in oxygen consumption by 6 fish group exhibited $22.7 \mathrm{~h}$ interval (Fig. 2C). The instantaneous rates of oxygen consumption by the 4 and 6 fish groups also showed minor peaks in short periods of 11.4 and $11.7 \mathrm{~h}$ intervals, respectively (Fig. 2B, C).

Mean oxygen consumption of the animals in each group was calculated by averaging over the entire duration of the experiments and entire range of oxygen saturations (Table 1). The mean ( \pm SE) oxygen consumption rates of fish kept at oxygen levels between 94.9 and $86.3 \%$ of saturation were $0.69 \pm 0.01 \mathrm{ml} \mathrm{O}_{2}\left(\mathrm{~g}\right.$ dry $\mathrm{wt}^{-1} \mathrm{~h}^{-1}$ for the $1 \mathrm{fish}$, $0.79 \pm 0.01 \mathrm{ml} \mathrm{O}_{2}(\mathrm{~g} \text { dry } w \mathrm{t})^{-1} \mathrm{~h}^{-1}$ in the 4 fish group, and $0.91 \pm 0.01 \mathrm{mi} \mathrm{O}_{2}$ (g dry wt) $)^{-1} \mathrm{~h}^{-1}$ in the 6 fish group, respectively. These values show that oxygen consumption rates slightly increased with increasing number of experimental fish placed in the chamber at a time.

\section{DISCUSSION}

Many researchers have reported that most marine fish exhibit rhythms of $12.4 \mathrm{~h}$ in their behaviour and metabolic processes coinciding with the rise and fall of tides, i.e. tidal rhythms (Northcott et al. 1990, 1991,
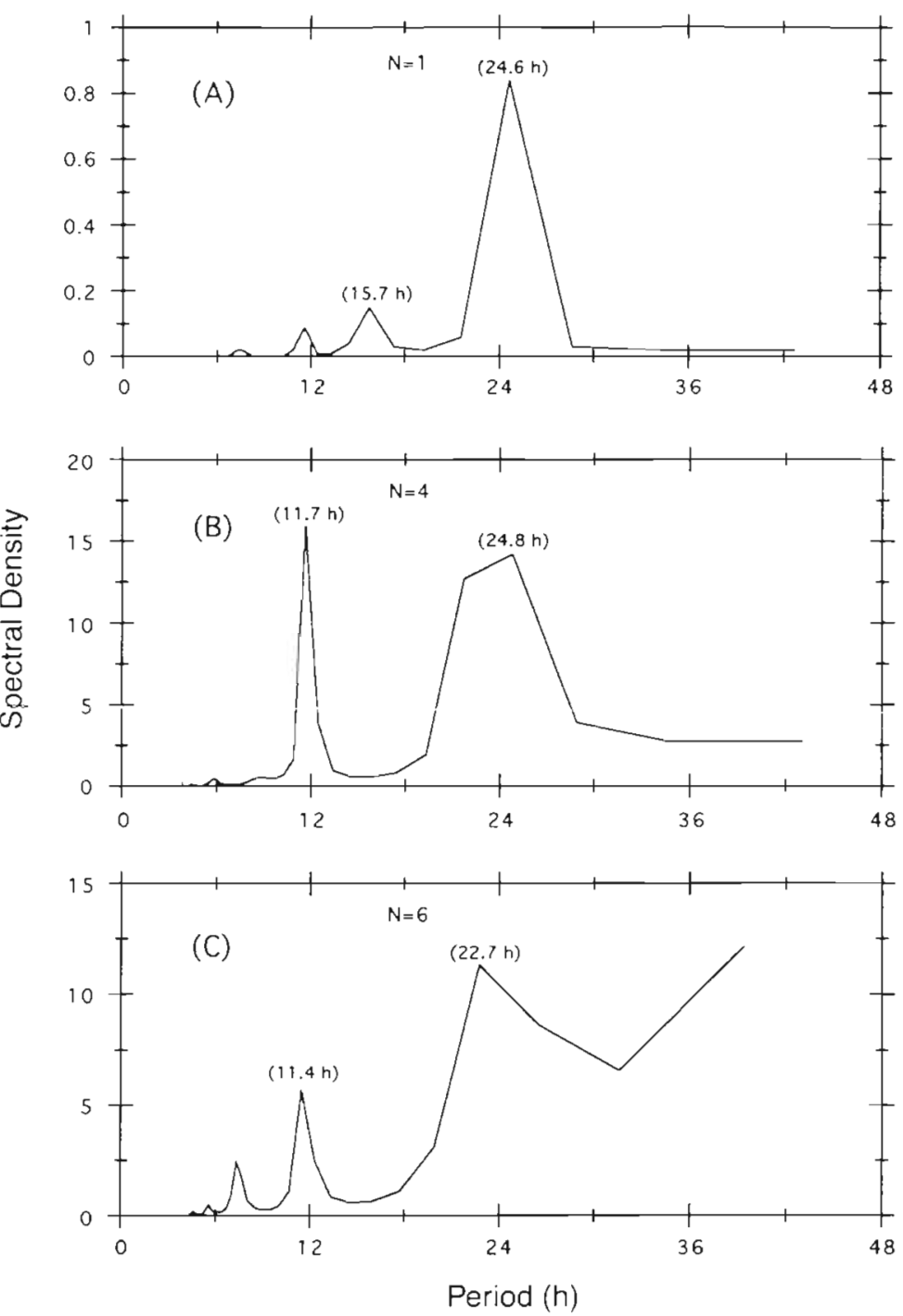

Fig. 2. Maximum Entropy Spectral Analysis (MESA) plots for (A) 1, (B) 4 , and (C) 6 river puffer fish Takifugu obscurus for the data sets presented in Fig. $1 A, B$, and $C$. Period lengths ( $h$ ) corresponding to dominant peaks in the MESA spectra are given in parentheses

Gibson 1992, Leatherland et al. 1992). In the present study, fish used were kept away from any external stimuli, such as light, food, temperature, salinity or tide, which may affect the rhythmic activity of the test subjects. Nevertheless, the river puffer fish exhibited a strong endogenous circadian rhythm in the instantaneous rate of oxygen consumption. However, the physiological significance of the minor peaks of oxygen consumption at 11.4 to $11.7 \mathrm{~h}$ intervals in the 4 and 6 fish groups cannot be immediately explained; whether they were due to group effects or had a genetic derivation is unknown. Currently, we only suggest that this is consistent with the view that fish reared in the labora- 
tory after insemination are much more likely to exhibit responses due to their living environment rather than of genetic derivation to circatidal fluctuations or certain geophysical forces, e.g. geomagnetism, which easily penetrates otherwise constant laboratory conditions (Palmer 1995). Further work is needed to elucidate the minor-peak phenomenon.

The gradual decrease or increase in both magnitude and amplitude of the oxygen consumption in this study was similar to those observed with other species (Shirely \& Findley 1978, Hastings 1981, Tankersly \& Forward 1994). Mean oxygen consumption rate in the rhythms of 1 fish appeared to gradually decrease with time $(\mathrm{r}=0.86, \mathrm{p}<0.05)$, while that in 4 fish increased $(\mathrm{r}=0.94, \mathrm{p}<0.05)$, as shown in Fig. 1B. A decrease in oxygen consumption could be due to starvation (Lewis 1971, Widdows \& Bayne 1971, Kim et al. 1996b). An increase in oxygen consumption could be partially due to effects of microbial respiration deriving from internal organs and some excretory materials of fish with time during experiments. However, these effects appeared not to be significant for the observation of endogenous rhythm in the river puffer fish in this study.

In the present study, differences between 'basal' oxygen consumption and maximum oxygen consumption were 260 to $810 \%$ for the 1 to 6 fish groups. A similar result (300 to $700 \%$ for 12 to 32 animals) was found in the oxygen consumption of a sand-beach isopod Tylos granulatus by Marsh \& Branch (1979)

The variation in oxygen consumption during the initial phase by the 6 fish group (Fig. 1C) can be interpreted as stress effects due to 'handling' (Reubush \& Heath 1996, Waring et al. 1996) or as 'non-steady-state effects' (Jobling 1981, Follum \& Gray 1987).

It is a generally known fact that oxygen consumption per unit weight is lower in fish in a larger group of fish than in isolated fish or fish in a small group (Itazawa et al. 1978, Kanda \& Itazawa 1981, Honda 1988). In this study, however, the oxygen consumption rates slightly increased with increasing number of fish in the experimental chamber. It could be partly due to differences in behaviour among species. For example, flounder in a large group are put at ease by visual contact with fellow fish and reduce their oxygen consumption (Itazawa et al. 1978), while puffer fish bite their fellow fish's tails when starved (Pyun \& Rho 1970), and thus increase oxygen consumption.

The observed rhythm of the river puffer fish appeared to be independent of oxygen levels between 94.9 and $86.3 \%$ of saturation, which are considered to be well above the critical oxygen concentrations. The critical oxygen levels which limit the respiratory process of a cichlid fish Oreochromis niloticus were below $25 \%$ of saturation (Fernandes \& Rantin 1989).
In conclusion, the rhythmicity of river puffer fish was found to be predominantly circadian. The use of an AIFR made it possible to measure the endogenous rhythm of oxygen consumption of fish, which is difficult to detect by way of conventional respirometers.

Acknowledgements. We thank Dr R. N. Gibson (Centre for Coastal and Marine Sciences, Oban, UK), Dr I. Y Ahn (KORDI), and Dr John D. Palmer (Woods Hole Oceanographic Institution, MA, USA) for their helpful comments on an earlier draft of the manuscript. We thank Dr $\mathrm{H}$. Dowse (University of Maine, USA) for graciously providing us with the Maximum Entropy Spectral Analysis (MESA) program. We also thank Dr Sinjae Yoo, Mr Sinkyu Kang (KORDI), and Mr C. Dietrich, for developing the computer program and graphucal analysus, and Mr Hyung-Sun Kim (KORDI) for providing laboratory samples of river puffer fish for this study.

\section{LITERATURE CITED}

Aagaard A, Andersen B, Depledge MH (1991) Simultaneous monitoring of physiological and behavioural activity in marine organisms using non-invasive, computer-aided techniques. Mar Ecol Prog Ser 73:277-282

Akiyama T (1995) Circatidal swimming activity rhythm in a subtidal cumacean Dimorphostylis asiatica (Crustacea). Mar Biol 123:251-255

Aldrich JC, McMullan PM (1979) Observation on non-locomotory manifestations of biological rhythms and excitement in the oxygen consumption rates of crabs. Comp Biochem Physiol 62A:707-709

Ameyaw-Akumfi C, Naylor E (1987) Temporal patterns of shell-gape in Mytilus edulis. Mar Biol 95:237-242

Bohn G (1903) Sur les mouvements oscillatories des Convoluta roscoffensis. C R Acad Sci 137:576-578

Chyung MK (1977) The fishes of Korea. Il-Si Sa Press, Seoul, p 605-606

Davies RW, Wrona FJ, Kalarani V (1991) Assesment of activity-specific metabolism of aquatic organisms: an improved system. Can J Fish Aquat Sci 49:1142-1148

Dorrien CF von (1993) Ecology and respiration of selected arctic benthic fish. Ber Polarforsch 125:1-99

Dowse HB, Ringo JM (1989) The search for hidden periodicities in biological time series revisited. J Theor Biol 139 $487-515$

Fanta EF, Lucchiari PH, Bacila M (1990) Circadian rhythm of oxygen consumption and oxygen levels in the muscle of Notothenia neglecta (Pisces, Teleostei). Comp Biochem Physiol 96C:151-155

Fernandes MN, Rantin FT (1989) Respiratory responses of Oreochromis niloticus (Pisces, Cichlidae) to environmental hypoxia under different thermal conditions. J Fish Biol 35:509-519

Follum OA, Gray JS (1987) Nitrogenous excretion by the sediment-living bivalve Nucula tenuis from the Oslofjord, Norway. Mar Biol 96:355-358

Gamble FW. Keeble F (1903) The bionomics of Convoluta roscoffensis with special reference to its cells. Proc R Soc $72: 93-98$

Gibson RN (1992) Tidally-synchronized behaviour in marine fishes. In: Ali MA (ed) Rhythms in fishes. Plenum Press, New York, p 63-81.

Hastings MH (1981) Semi-lunar variations of endogenous circa-tidal rhythms of activity and respiration in the Isopod Eurydice pulchra. Mar Ecol Prog Ser 4:85-90 
Honda H (1988) Displacement behavior of Japanese flounder Paralichthys olivaceus estimated by the difference of oxygen consumption rate. Nippon Suisan Gakkaishi 54: 1259

Itazawa T, Matsumoto T, Kanda T (1978) Group effects on physiological and ecological phenomena in fish - I. Group effect on the oxygen consumption of the rainbow Trout and Medaka. Nippon Suisan Gakkaishi 44:965-969

Jobling $M$ (1981) The influence of feeding on the metabolic rate of fishes: a short review. J Fish Biol 18:385-400

Kanda T, Itazawa Y (1981) Group effect on oxygen consumption and growth of the catfish Eel. Nippon Suisan Gakkaishi 47:341-345

Kim WS, Jeon JK, Lee SH, Huh HT (1996a) Effects of pentachlorophenol (PCP) on the oxygen consumption rate of the river puffer fish Takifugu obscurus. Mar Ecol Prog Ser 143:9-14

Kim WS, Rumohr H, Schmid MK, Koh CH (1996b) A rhythmicity in the rate of oxygen consumption by the Manila clam, Ruditapes philippinarum. J Korea Soc Oceanogr 31: $117-122$

Lampert W (1984) The measurement of respiration. In: Downing JA, Riegier Fi (eds) A manuai on methods íor the assesment of secondary productivity in fresh waters. IBP Handbook No. 17 Blackwell Scientific Publications, Oxford, 4 4.13-468

Leatherland F, Farbridge KJ, Boujard T (1992) Lunar and semi-iundr rhyihnns ins fisiles. In: Ải ive fedj Rhythms in fishes. Plenum Press, New York, p 83-107

Lewis JB (1971) Comparative respiration of some tropical intertidal gastropods. J Exp Mar Biol Ecol 6:101-108

Marsh BA, Branch GM (1979) Circadian and circatidal rhythms of oxygen consumption in the sandy-beach Isopod Tylos granulatus Krauss. J Exp Mar Biol Ecol 37:77-89

Mehner T, Wieser W (1994) Energetics and metabolic correlates of starvation in juvenile perch (Perca fluviatilis) J Fish Biol 45:325-333

Northcott SJ, Gibson RN, Morgan E (1990) The persistence and modulation of endogenous circatidal rhythmicity in Lipophrys pholis (Teleostei). J Mar Biol Assoc UK 70 : $815-827$

Northcott SJ, Gibson RN, Morgan E (1991) The effect of tidal cycles of hydrostatic pressure on the activity of Lipophrys pholis (L.) (Teleostei). J Exp Mar Biol Ecol 148:35-45

This article was submitted to the editor
Palmer ID (1988) Comparative studies of tidal rhythms. VI. Several clocks govern the activity of two species of fiddler crabs. Mar Behav Physiol 13:201-219

Palmer JD (1989) Comparative studies of tidal rhythms. VIII. A translocation experiment involving circalunidian rhythms. Mar Behav Physiol 14:231-243

Palmer JD (1995) The biological rhythms and clocks of intertidal animals. Oxford University Press, Oxford

Palmer JD, Williams BG (1993) An organismic tidal rhythm with a peculiar phenotype. In: Aldrich JC (ed) Quantified phenotypic responses in morphology and physiology. Proc 27th Eur Mar Biol Symp, Dublin, Ireland, 1992. JAPAGA, Ashford, p 121-127

Pyun CK, Rho S (1970) Breeding of the puffer Fugu rubripes. Bull Korean Fish Soc 3:52-64

Reid DG, Naylor E (1989) Are there separate circatidal and circadian clocks in the shore crab Carcinus maenas? Mar Ecol Prog Ser 52:1-6

Reubush KJ, Heath AG (1996) Metabolic responses to acute handling by fingerling inland and anadromous striped bass. J Fish Biol 49:830-841

Shirely TC. Findley AM (1978) Circadian rhythm of oxygen consunptiun in the massh periwinkle, Littorina irrorata (Say, 1822). Comp Biochem Physiol 59A:339-342

Steffensen JF (1989) Some errors in respirometry of aquatic breathers: how to avoid and correct for them. Fish Physiol Biochem 6:49-59

Tankersley RA, Forward RB Jí (1994) Endogenous swimming rhythms in estuarine crab megalopae: implications for flood-tide transport. Mar Biol 118:415-423

Waring CP, Stagg RM, Poxton MG (1996) Physiological responses to handling in the turbot. J Fish Biol 48:161-173

Weiss RF (1970) The solubility of nitrogen, oxygen, and argon in water and seawater. Deep Sea Res 17:721-735

Widdows J, Bayne BL (1971) Temperature acclimation of Mytilus edulis with reference to its energy budget. $J$ Mar Biol Assoc UK 51:827-844

Wrona FJ, Davies RW (1984) An improved flow-through respirometer for aquatic macroinvertebrate bioenergetic research. Can J Fish Aquat Sci 41:380-385

Zeng C, Naylor E (1996) Endogenous tidal thythms of vertical migration in field collected zoea-1 larvae of the shore crab Carcinus maenas: implications for ebb tide offshore dispersal. Mar Ecol Prog Ser 132:71-82

Manuscript first received: January 13, 1997

Revised version accepted: April 28, 1997 